\title{
The effect of project on children attitude toward environmental balance
}

\author{
ABDUL RAHMAN N.* (1), MOHD YUSOP N. (1) and AWANG R. (1)
}

Institut Aminuddin Baki Cawangan Genting Highlands, Malaysia

\section{RESEARCH ARTICLE}

Received: September 17, 2020 • Accepted: May 27, 2021

Published online: December 13, 2021

(c) 2021 The Author(s)

\begin{abstract}
The purpose of this study is to explore the effect of project on children's attitude toward environmental balance. This study is a qualitative study using a holistic single case study design involving "compost cases", at a kindergarten in Perak, Malaysia. The participants consisted of a focus group of 18 children and an educator. The data was obtained through triangulation results from unstructured interview, observation, and unofficial documents such as children notebooks, sketches, and pictures of investigative activities. The findings showed that the children understand the negative impact of using chemicals on Earth. The finding also showed that children able to give suggestions on producing compost, burying food scraps in the soil and use the compost dining set for banquet to deal with waste management problems. In addition, the finding showed that children able to classify waste materials which is easily decompose for compost production. The finding also showed that activities project able to develop entrepreneurial attitudes in children to sell the product produced. The valuable experience through observation and hands-on activities from early childhood will help the continuity of learning process throughout their lives.
\end{abstract}

\section{KEYWORDS}

sustainability, project approach, early childhood education, environment

\footnotetext{
*Corresponding author. E-mail: norazizahabdulrahman@gmail.com
} 


\section{INTRODUCTION}

In tandem with the rapid development, rising urbanization rates, increasing population and increasing socioeconomic status towards developed countries have had a hidden impact on today's Malaysian society scenario. The most significant impact facing the Malaysian public today is the production of domestic waste which causes pollution (Mohamad Taha \& Mohamad, 2015; Abdul Rauf \& Mohamad, 2013). In addition, reports from the Ministry of Urban Wellbeing, Housing and Local Government (KPKT, 2014) show that with each passing year the pattern of increasing waste volume is increasing.

Initially, the total waste generation in the country in 2005 was only 19,000 tonnes per day but increased sharply to 33,000 tonnes per day in 2013 (KPKT, 2014). The rate of solid waste generation (waste) per person also increased from $0.85 \mathrm{~kg}$ per day to $1.14 \mathrm{~kg}$ per day over the same period. This is due to the low level of awareness of the Malaysian community on recycling practices of $10.5 \%$ compared to developed countries with levels of awareness higher than $40 \%$ (SWCorp, 2016).

This is because the attitude of the people who do not prioritize cleanliness in everyday life has had many negative effects on environmental issues. Global warming has an impact on rising sea levels and rising global temperatures as well as affecting the natural environment and ecosystems (Abdul Rauf \& Mohamad, 2013). If this pattern continues, it will have adverse environmental impacts such as greenhouse gas emissions (GHG) and pollution to water and land resources (SWCorp, 2015).

On the other hand, the failure of the municipalities in regulating and maintaining the landfill sites has a negative impact on ensuring sustainable access to Malaysia (Agamuthu \& Fauziah, 2014). However, Agamuthu (2007) argues that composting processes need to be practiced in Malaysia as this practice has the potential to enhance environmental sustainability especially at waste disposal sites. Baki et al., (2015) found that organic matter generated from earthworm decomposition activity on food waste is the best technique for reducing pollutants from solid waste dumped at landfill sites.

Through the study of vermicompost bins, they prove that before the expiration of some organic decomposition process will be eaten by earthworms and released as "worm poo" or "vermikas", and some will continue to rot into compost waste. In addition, the last product produced shows an increase in nutrients in the soil.

In the context of the environment, Hotinli (2004) finds that increasing knowledge and awareness of the environment are two important elements in building the nation's capacity towards environmental sustainability. Education is seen to play a major role in shaping the human mind, thinking and attitude towards good.

In this regard, the teaching and learning approach of the environment through the composting project will enable one to change one's mind, attitude and practices towards loving the environment in whatever action they take. Othman and Yahaya (2011) also expressed the view that environmental education is an important element in improving the quality of the environment. The effectiveness of this quality is through fertilizing and seeding awareness about the importance of preservation and conservation of the environment in the daily life of every human being.

In addressing an environmental issue, project activities are seen as an alternative approach to shaping future generations. Thus, in the early stages of children's education, the project was an open study of topics in daily life that were integrated into one educational program. Projects are 
based on questions raised by children based on their interests. Usually, educators are more likely to provide immediate answers to questions posed by children, but through project activities, educators provide knowledge-based experiences beyond the box of thought (Hart, 2013). Where children can find their own answers through investigations while doing fieldwork or interviewing experts or through parent involvement (Helm \& Beneke, 2003). In this regard, this study aims to explore children's awareness of the environment through composting project activities.

\section{Environmental education and early childhood education}

The National Preschool Standard Curriculum (KSPK) has been formulated and implemented in line with the 10th Malaysia Plan. KSPK's goal is to develop the potential of four to six year old children in a holistic and integrated manner in physical, emotional, spiritual, intellectual and social aspects through a safe, nurturing learning environment as well as fun, more creative and meaningful activities (Malaysian Education Ministry, 2010).

This is enshrined in the 15th and 19th objectives of the Preschool Curriculum Standard Document (DSKP) (Ministry of Education Malaysia, 2010a), which is to explore the environment using basic science process skills and appreciate the beauty of the environment and cultural heritage. This is to improve skills, instil confidence and form a positive self-concept in children so that they are successful in the existing environment and ready to face challenges (Malaysian Education Ministry, 2010).

Overall, KSPK shows a balance of emphasis on the six main pillars in the formation of a balanced perfect human capital. Among the aspects that are given priority are the pillars of humanity which provide opportunities for children to better understand themselves and better know and understand the relationship between themselves and family, friends, community and the environment (Malaysian Education Ministry, 2010).

The humanitarian aspect applied through the educational process is the mainstay of environmental control and sustainable development. This is because the school is one of the centers to prepare children to address issues related to the environment Ministry of Education Malaysia, (2010). Even the formation of a balanced human capital can only be born when these three elements are met, namely knowledge, skills and the application of positive values.

In the context of Malaysia, Environmental Education has been introduced by integrating it through all subjects. However, at the preschool level Environmental Education across the curriculum only began in 2005. Environmental Education across the Curriculum was first introduced with the publication of the Environmental Education Educator's Guidebook used by all educators during the teaching process (Malaysian Education Ministry, 2010).

\section{Project based learning in preschool curriculum in Malaysia}

Project-Based Learning which was introduced by the Ministry of Education Malaysia in 2006 is a learning process that occurs through assignments with the ultimate goal, children produce a project. project-based learning is considered a best practice in the learning process because it prioritizes projects in teaching and learning (Kaldi, Filippatou, \& Govaris, 2011) as well as is an instructional method that gives children the opportunity to use specific skills to produce a product or artifact (Zimmerman, 2000).

The characteristics of project-based learning described by the Ministry of Education Malaysia (2012) based on 21st Century Learning is to include the role of children carrying out 
project activities in a certain period of time and beyond the time allocated in the classroom. Children are given the opportunity to speak up and present ideas by forming open-ended questions that relate to what they need to learn. Children also determine the title, key questions, resources and products to be produced. In this regard, collaborative learning can generate critical and creative thinking in real situations as well as improve the $4 \mathrm{C}$ skills of "communication, collaboration, critical thinking and creativity” (Ministry of Education Malaysia, 2012).

\section{Research questions}

In general, researchers want to explore one of the key questions, what the effect of project on children attitude toward environmental balance?

\section{METHOD}

\section{Research design}

This study focuses on environmental project activities generated through the project approach. In the meantime, the duration of the exploratory activities was 6 months from January to May 2016. In the meantime, the activity was aimed at exploring children's knowledge and awareness of the environment. In addition, the involvement of educators and parents is seen as shaping children's culture and behaviour towards environmental literacy.

\section{Location and participants}

This kindergarten is located in the National Child Development Research Center (NCDRC) complex located at the Sultan Idris University of Education (UPSI), Tanjung Malim, Perak Malaysia. Meanwhile, the study participants consisted of focus groups of 18 children from class 6 Sakura which is consist of 5-6 years (5+-) old children. The parents' permission was obtained for participation of children in this research.

\section{Various sources of data collection}

For the purpose of this study, researchers made observations using two main methods: video recording, and secondly through observation notes. The results of the observations were recorded in writing in preparation for the report using the "learning story" technique adapted from QCAA 2016. In fact, the findings showed that the presence of video and MP3 recording did not interfere with children's attention and attention during the teaching and learning process. In addition, in this study researchers used open observation techniques to detect something they wanted to focus on. Or, in other words, using the participant observation technique where the researcher engages in a group of study participants and the presence of the researcher is recognized by the study participant to make the observation in the actual situation (Miles, Huberman, \& Saldana, 2013).

To obtain a detailed understanding and description of the implementation of environmental activities through the Project Approach, researchers have made observation or field notes. This note proposes (1) the place or location of the observation, (2) the behaviour before, during and after the observation, (3) the expression of emotion, (4) the writing of "verbatim" (verbal 


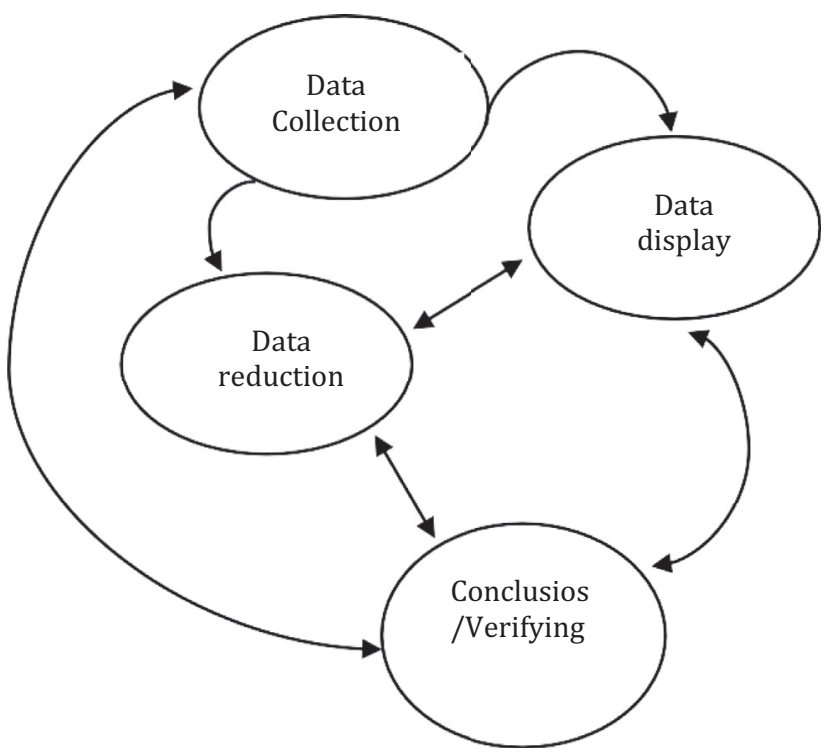

Fig. 1. Interactive data analysis. Adapted from (Miles \& Huberman, 2013)

expression by word) and (5) body language signals during the study participants expressing their feelings or thoughts.

For the purpose of this study, researchers gather the data from unofficial documents consisting of written material such as teachers' journals, children notebooks, sketches, and pictures of investigative activities.

The data compiled through a process of analytical studies and analysed using content analysis and narrative analysis. In this study, data collected through observations, interviews and documentary evidence were analysed based on the approach proposed by Miles et al. (2013), which consisted of four main components: (1) data collection, (2) data reduction, (3) display the data, and (4) conclude and verify (Fig. 1).

\section{RESULTS AND DISCUSSION}

The results show that recycling activities can foster children's attitudes towards environmental sustainability. From the observations, interviews and sketches produced through the activities of this project, children can understand the impact of using chemicals on Earth. Children are able to give suggestions on how to deal with waste management problems and classify waste materials for compost production.

\section{Choose to use compost: understand the impact of using chemicals on Earth}

Children understand that the use of pesticides can negatively affect consumers. In fact, children are more confident in the use of compost fertilizer than chemical fertilizers. This 
is because chemicals can cause the Earth to be threatened. Interviews between children and researchers indicate that children are more concerned with the use of compost fertilizer.

\begin{tabular}{|c|c|c|}
\hline RE5 & & We can do this fertilizer on our own, it does not get itchy. \\
\hline Researchers & : & Why isn't the hand itching? \\
\hline RE1 & : & $\begin{array}{l}\text { We do not use insecticides. In Cameron Highlands, there are many vegetables, but they } \\
\text { use chemical fertilizers! }\end{array}$ \\
\hline Researchers & : & really! in Cameron Highlands they use insecticides? \\
\hline RE2 & : & $\begin{array}{l}\text { My mom told me there was fresh vegetables in Cameron Highland because they used } \\
\text { chemical fertilizers. That's why we grow vegetables using our own fertilizer. Even eating } \\
\text { doesn't hurt your stomach. The Earth is safe. }\end{array}$ \\
\hline RE5 & & $\begin{array}{l}\text { If we use chemical fertilizers for a long time our Earth will not survive. All animals and } \\
\text { plants can die. }\end{array}$ \\
\hline RE1 & & Teacher ... we want to make our own compost fertilizer! \\
\hline
\end{tabular}

RE3(2)I-06/4 (row 55-66)

In relation to children's attitudes and knowledge, a study by Palmer, Grodzinska-Jurczak, and Suggate (2003), also revealed that children as young as 4 years of age have the correct knowledge of the waste disposal process and most children can understand that waste disposal has a procedure in order. The study also reports that children's day-to-day observations of garbage trucks that are regularly scheduled at school and at home also reinforce knowledge about waste disposal as well as exposure to recycling programs and waste disposal sites through the internet also helps children deal with the issue of waste.

\section{Able to give suggestions on how to deal with waste management problems}

Children are able to made several suggestions in addressing the issue of waste management such as producing compost, burying food scraps in the soil and use the compost dining set for banquet. These ideas are acquired by the children through daily experiences at home and also gained through field work activities during project activities. This situation shown that children are developing an understanding of the role that they can play in global conservation for maintaining environmental sustainability. However, children are more likely to show a deep interest in composting.

Observations and interviews show that children have come up with a sensible proposal in addressing the environmental issue of making compost fertilizer as an alternative to environmentally friendly fertilizer ( $\mathrm{RE}$ (20) O/RV-06/4, paragraph 10). The RE abbreviation refers to the study participants (children) in the first focus group for the Composite Fertilizer Case study. Children able to explain and suggest to keep the environment clean, food waste can be treated as compost (RE1), burying in the soil (RE2) and use compost dining set (RE3). 


\begin{tabular}{|c|c|c|}
\hline$R E 1$ & & $\begin{array}{l}\text { Near the market there are many greens that are still green but sellers throw away. We } \\
\text { can take it for free and make compost! }\end{array}$ \\
\hline Researcher & : & Why should we use that vegetable to fertilize? It's good that we throw it away! \\
\hline RE1 & & $\begin{array}{l}\text { Aaa... how can the vegetable be thrown away because it smells bad. The market is going } \\
\text { to get dirty. }\end{array}$ \\
\hline Researcher & : & But teacher saw someone near the market dumping the vegetables in the trash! \\
\hline RE1 & & $\begin{array}{l}\text { Because the trader must not know that! The vegetables can be compost. Once fertilized } \\
\text { we can use it near Edible Garden. Haa, on the lady finger or spinach or roselle tree! } \\
\text { RE1(2)I-06/4 (row 55-66) }\end{array}$ \\
\hline RE2 & & We also can buried leftover food in the soil. ..my dad. . always do that. . in my garden \\
\hline Researcher & & Leftover food? That's only? \\
\hline RE2 & & No la teacher... he also put broh \\
\hline Researcher & : & Why it safe for us? \\
\hline RE2 & & No more we can see unwanted thing...here and there. \\
\hline RE3 & : & $\begin{array}{l}\text { RE2(2)I-06/4 (row } 44-48) \\
\begin{array}{l}\text { My mom. . always use compost dining set. . for party time. . . sometime. . . used for lunch } \\
\text { time. . . }\end{array}\end{array}$ \\
\hline Researcher & & Why your mom used that? \\
\hline RE3 & & $\begin{array}{l}\text { We can save time, do not wash, just throw away... an it easily broken. . . if we put in the } \\
\text { soil it can turn to compost... sooo safe... better we use this thing in our school. } \\
\text { RE3(2)I-06/4 (row 72-76) }\end{array}$ \\
\hline
\end{tabular}

The findings show that children have successfully made wise suggestions in addressing environmental issues.

\section{Able to classify waste materials for compost production}

Children can classify, list and draw out waste material for compost production (Fig. 2). The children only choose food waste from their house which is easily decompose. Then, they bring food waste such as vegetables, bread, fruit skins, dried leaves and eggshells to produce compostable fertilizers at their school. Children do not choose plastic or material made from metal in making compost.

In this regard, children have undertaken hands-on activities of composting fertilizers using their own compost materials (Fig. 3).

Through this activity, children can observe directly the effects of decomposition processes on compost materials. Children can smell bad odour as well as the production of liquids as a result of decomposition of compost materials. This experience can be explained through Fig. 4 showing the activities of children performing the process of composting fertilizers that have undergone decomposition.

In addition, children can also make predictions about the result that can be seen in the compost bin by drawing a sketch like Document DT05 (11/04/16) (Fig. 5). 


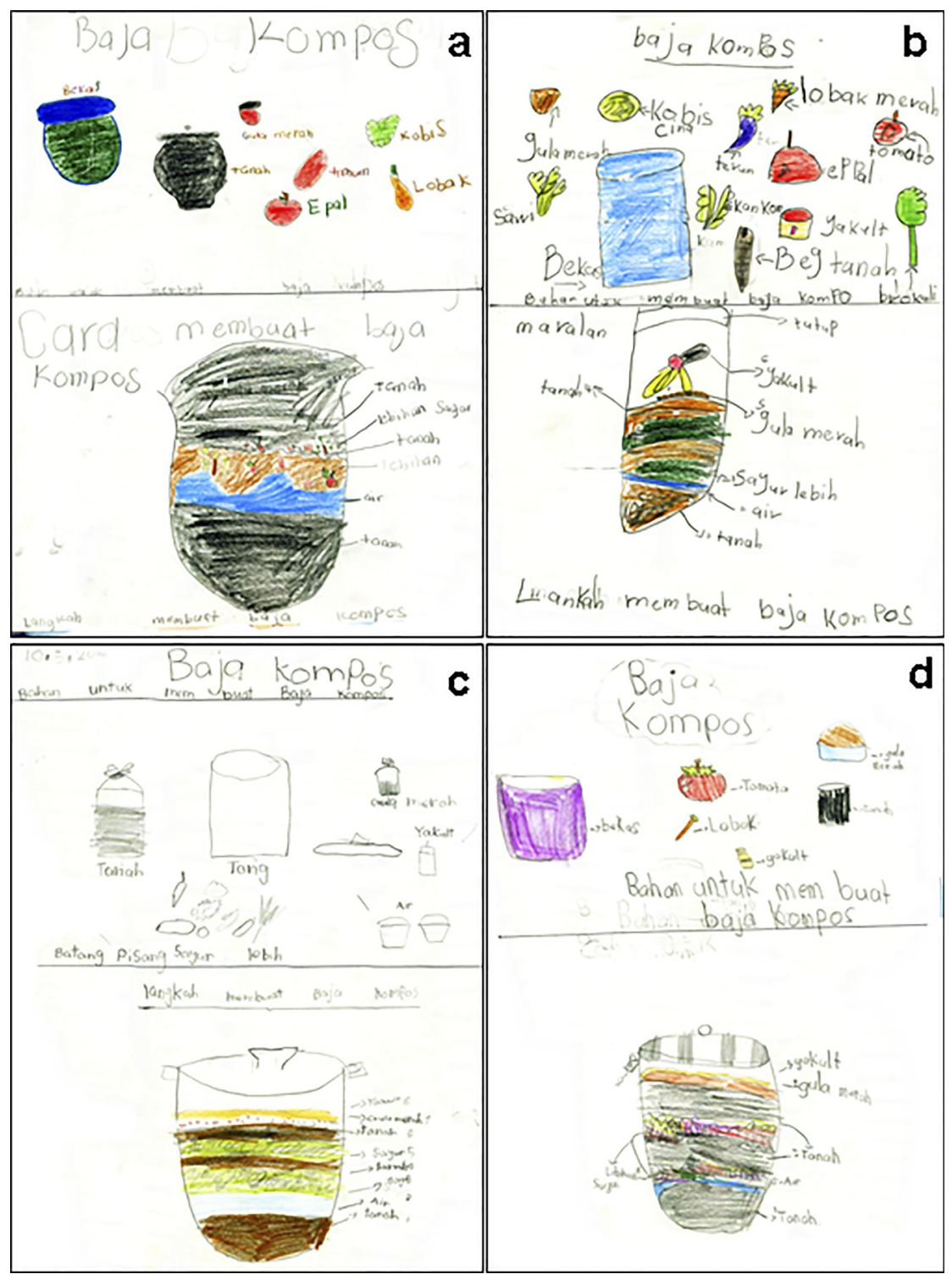

Fig. 2. Sketch of waste material for composting steel production 

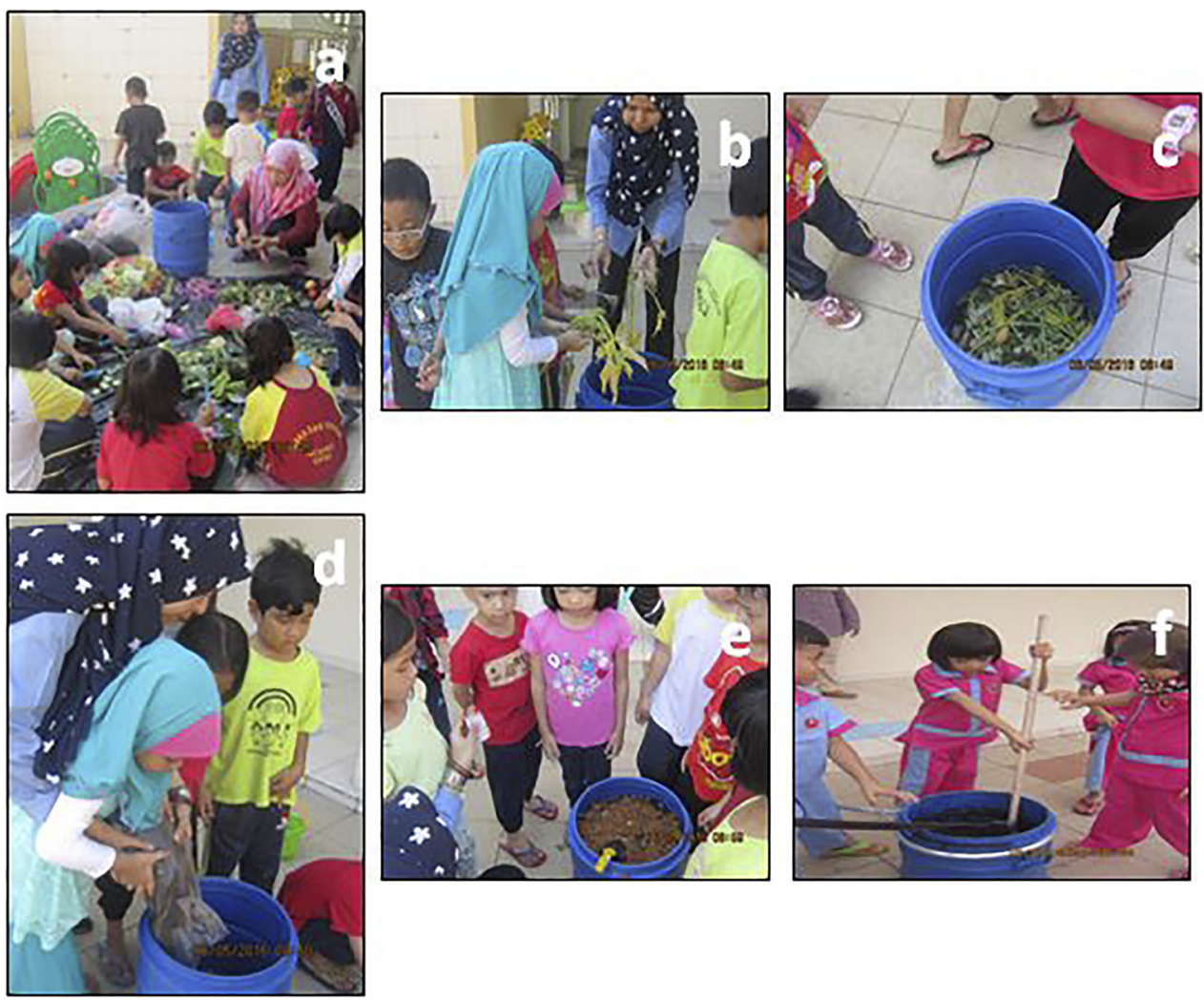

Fig. 3. The process of composting by children. a) the residue of compost brought from the house, b) the compost residue is placed into the drum, c) residual compost is mixed with soil, d) Red sugar is included, e) Yakult beverages (bacteria to speed up decomposition of food waste) are also included, and f) the mixture inside the drum is mixed

The finding show that children have their own idea to get rid of leftover food, plant material and other biodegradable items to produce compost (Fig. 3). This shows that new knowledge gained through field work helps children to come up with new ideas about the materials that can be used to produce compost.

\section{Develop entrepreneurial attitudes in producing compost}

Project activities in producing compost also develop entrepreneurial attitudes in children. The result has shown the children's test their compost to grow mulberry plant. Document DT09 (25/ 4/16), shows that mulberry trees can only grow by using compost mixes with other soil. The children sell mulberry trees and compost fertilizer to parents, friends and teachers on their school open day. They also explain the process of making compost and grow the mulberry trees (Fig. 6). 

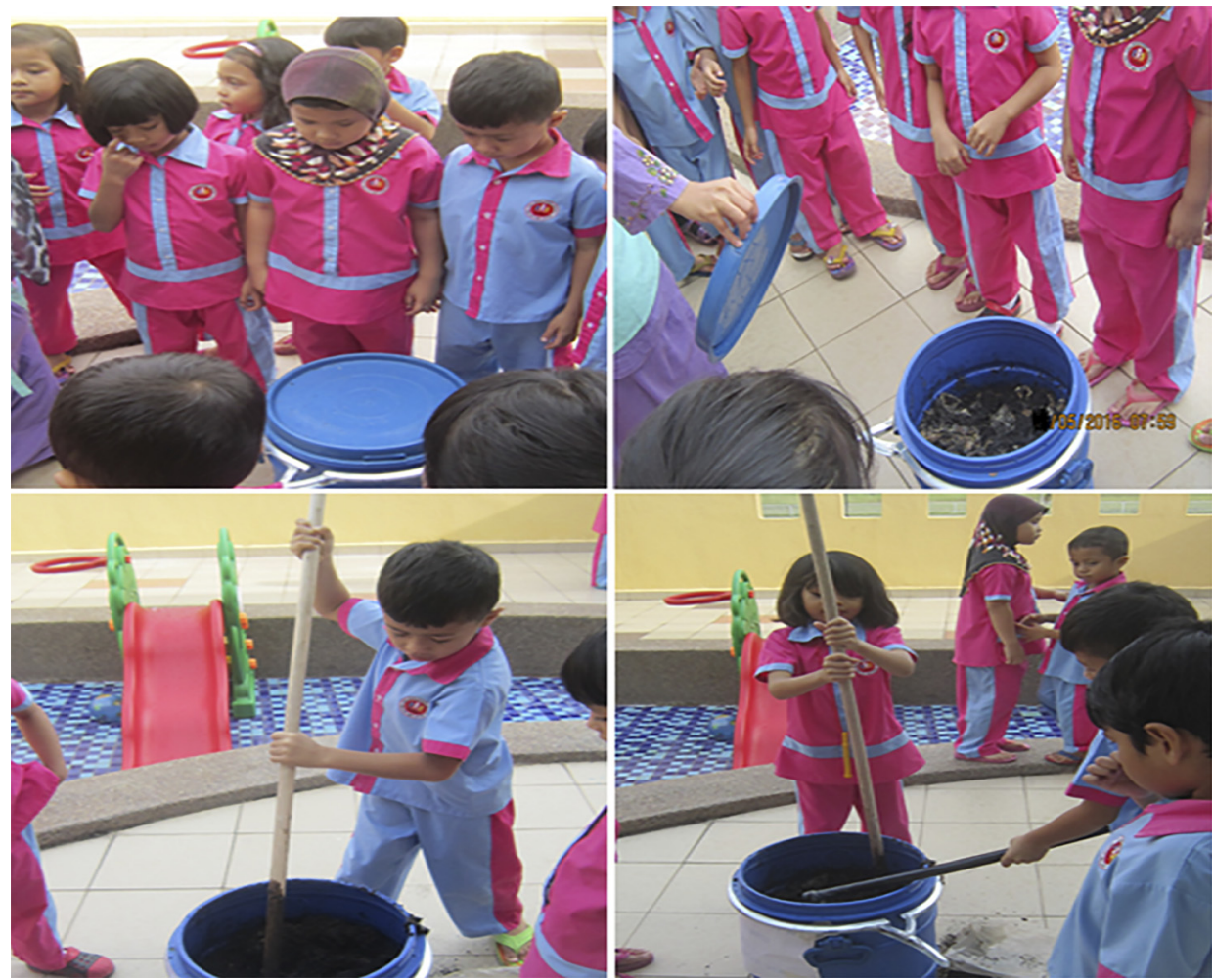

Fig. 4. The children take turns mixing the steel compost

\section{CONCLUSION}

For preschool children, project work is the more formal and teacher directed part of the curriculum. However, project work in this study provides a greater sense of self direction and personal involvement in school learning. The opportunities are given to children in generate their own idea about the material that can be used for making compost fertilizer.

In addition, through project activities children act as apprentices in addressing environmental issues. Children able to learn new skills, have fun, play and develop self-confidence by spending time in the garden growing their own mulberry plants using their compost fertilizer.

However, the children learn about the concept of re-use of waste materials for the production of new materials such as compost. In fact, children know that the act of producing compost can help preserve the environment from being polluted by domestic waste. The children gain experience naturally by making observations on the decomposition process. This valuable experience is gained from early childhood to help the continuity of learning throughout their lives. 


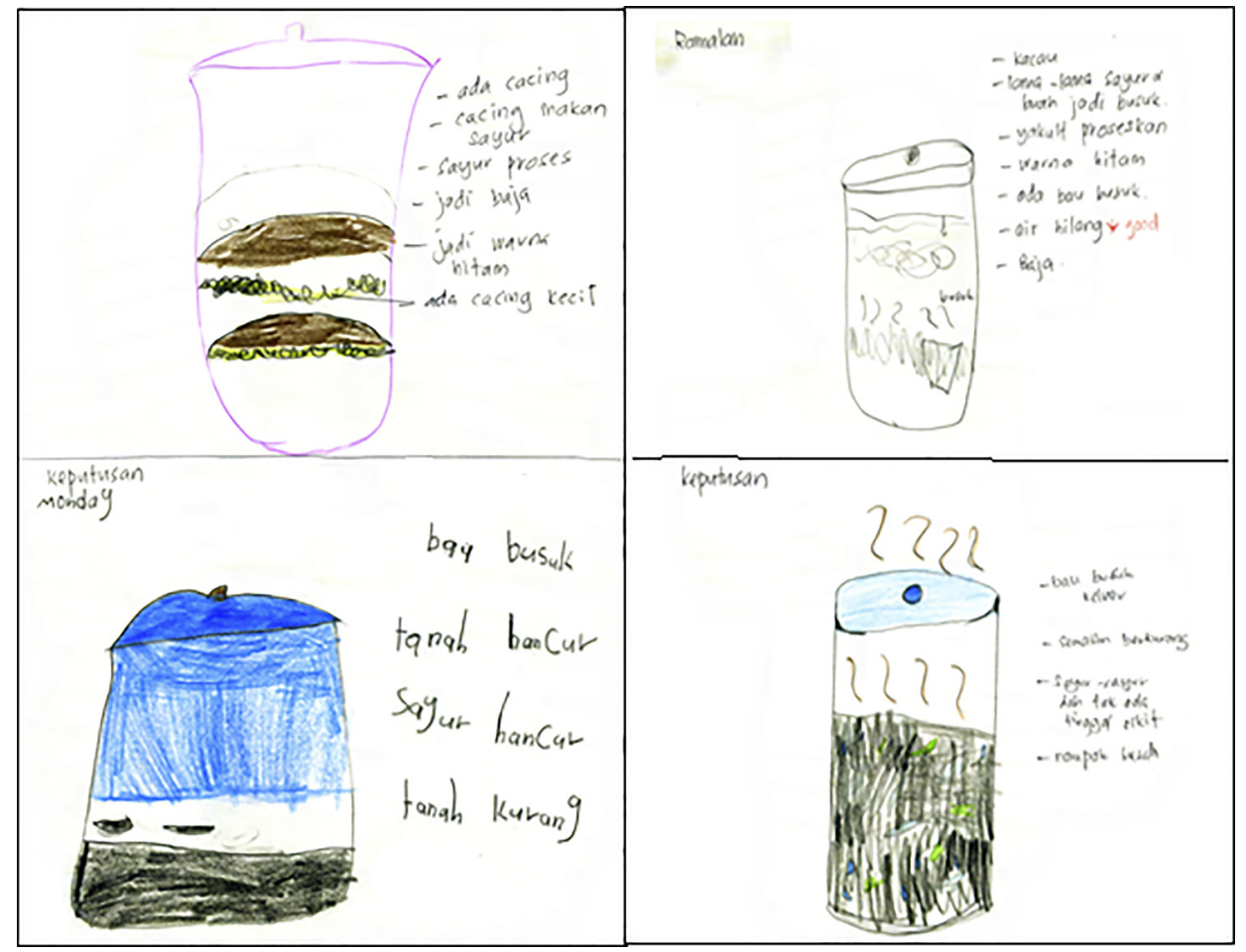

Fig. 5. Prediction of result in compost bin made by children 


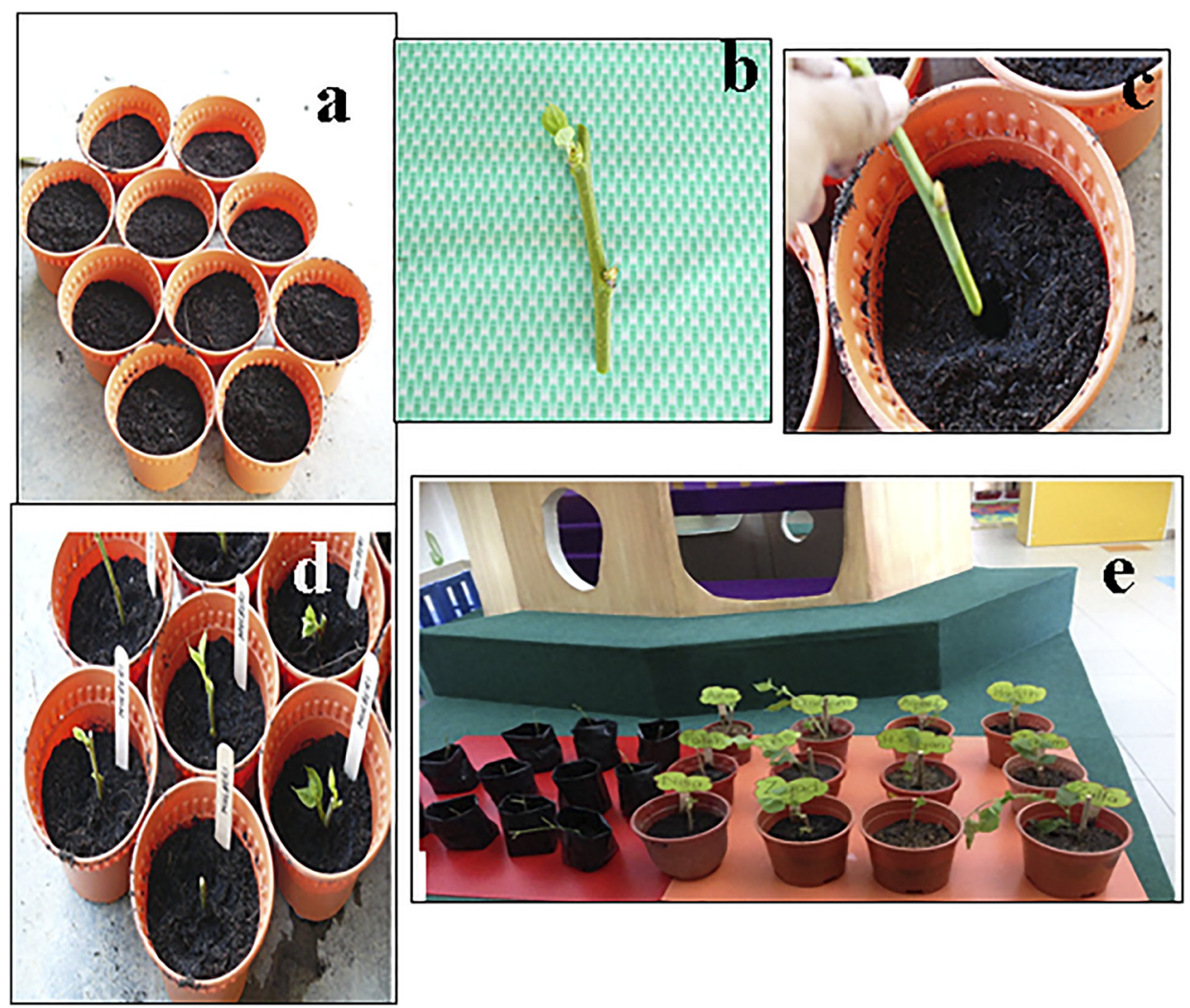

Fig. 6. Mulberry plants use compost fertilizers by children. a) Put soil (compost) into pots, b) Mulberry tree trunks, c) Insert a trunk cut into pots containing compost, d) Growth of mulberry seedlings using compost, and e) Mulberry crop for sale 


\section{ABOUT THE AUTHORS}

Norazizah Abdul Rahman, PhD. Lecturer at the Institute of Teacher Education in Malaysia. Research interests in Science Education and Environmental Education for early childhood and primary education.

\section{REFERENCES}

Abdul Rauf, R. A., \& Mohamad, S. R. (2013). Green environment awareness module to enhance responsibility and sensitivity towards the environment. Journal of Social and Development Sciences, 4(11), 494.

Agamuthu, P. (2007). Wet market waste to value-added product. The Ingenieur, 34, 38-41.

Agamuthu, P. \& Fauziah, S. H. (2014). Sustainable 3R practice in Asia and pacific region: The challenges and issues. In P. Agamuthu \& M. Tanaka (Eds.), Municipal solid waste management in Asia and the Pacific Islands (pp. 15-40). Singapore: Springer.

Baki, A., Mohd Rashid, A. N., Kassim, J., Shukor, M. F. Ramli, S., Jaafar, J., Mohd Zaki, Z., Atan, I., Ashaari, Y. \& Shamsudin, M. B. (2015). Sustainable campus: Solid waste minimisation using vermicomposting. Journal of Science and Management, 10(2), 74-87.

Hart, R. A. (2013). Children's participation: The theory and practice of involving young citizens in community development and environmental care. Routledge.

Helm, J. H. \& Beneke, S. (2003). The power of projects: Meeting contemporary challenges in early childhood classrooms strategies and solutions. (Vol. 87). Teachers College Press.

Hotinli, G. (2004). Environmental education in Turkey. In MIO-ECSDE. The status of environmental education in the Mediterranean countries within the formal and non-formal educational systems. Mediteterranean Information Office - for Environment, Culture, and Sustainable Development. Retrieved from https://www.mio-ecsde.org. [Assessed 30 Dec 2017].

Kaldi, S., Filippatou, D., \& Govaris, C. (2011). Project-based learning in primary schools: Effects on pupils' learning and attitudes. Education 3-13, 39(1), 35-47.

KPKT (2014). Ministry of Urban Wellbeing, Housing and Local Government strategy plan: Determinants of success. Retrieved from http://www.kpkt.gov.my/resources/index/user_1/GALLERY/PDF_ PUBLISHING/PLAN_STRATEGIC/PLAN_STRATEGIC_KPKT_2016_2020.pdf.

Malaysia Education Ministry. (2012). Malaysia education development plan 2013-2025. Putrajaya: Curriculum Development Division.

Malaysian Education Ministry. (2010). National preschool standard curriculum 2010. Curriculum Development Division.

Miles, M. B., Huberman, A. M. \& Saldana, J. (2013). Qualitative data analysis, London: Sage.

Mohamad Taha, M. F. \& Mohamad, M. (2015). Malaysia towards the 10 cleanest countries in the world. Bulletin of the Ministry of Urban Wellbeing, Housing and Local Government, 2, 15-18.

Othman, M. \& Yahaya, N. (2011). Sustainable use: How do teenagers behave? Publisher University Putra Malaysia.

Palmer, J. A., Grodzinska-Jurczak, M. \& Suggate, J. (2003). Thinking about waste: Development of English and Polish children's understanding of concepts related to waste management. European Early Childhood Education Research Journal, 11(2), 117-139. 
SWCorp (2015). Prosperous life: SWCorp annual report 2014. Putrajaya: Ministry of Urban Wellbeing, Housing and Local Government.

SWCorp (2016). Kehidupan sejahtera: Laporan tahunan SWCorp 2015. Putrajaya: Ministry of Urban Wellbeing, Housing and Local Government.

Zimmerman, C. (2000). The development of scientific reasoning skills. Developmental Review, 20(1), 99149. https://doi.10.1006/drev.1999.0497.

Open Access. This is an open-access article distributed under the terms of the Creative Commons Attribution-NonCommercial 4.0 International License (https://creativecommons.org/licenses/by-nc/4.0/), which permits unrestricted use, distribution, and reproduction in any medium for non-commercial purposes, provided the original author and source are credited, a link to the CC License is provided, and changes - if any - are indicated. 